\title{
The Debate on the Concept of the Person in Bioethics*
}

\author{
Debata na temat koncepcji osoby w bioetyce
}

\section{Grzegorz Hołub}

Faculty of Philosophy, Pontifical Academy of Theology in Krakow, Poland

ORCID: https://orcid.org/0000-0002-0312-3693• grzegorz.holub@upjp2.edu.pl

\begin{abstract}
This article endeavours to sketch the debate about the concept of a person in the realm of bioethics. Initially, it sets out three understandings of the issue, namely the concept of a person in naturalistic philosophy, in the current of communitarianism and in one of the humanistic positions. The analysis of these approaches lead to the conclusion that a human person is perceived either as an empirical and psychological entity or as a free subjectivity creating him/herself. This thesis provides stimulation for further research. In order to avoid a kind of dualism in the perception of a person stemming from the stances outlined above, the personalistic approach is developed. This points out that a human being should be depicted as one indivisible entity unifying in itself more strictly its self, a subjective aspect of the person, with nature-body aspect which is an objective facet of being human. Given this personalistic perspective, a person comes out as an embodied subjectivity formed by the unique personal act of existence. In this article, such a concept of a person is argued as a vital support in the complex field of bioethical dilemmas.
\end{abstract}

Keywords: person, naturalism, communitarianism, humanism, personalism

Streszczenie: W artykule podjęto próbę naszkicowania debaty w dziedzinie bioetyki dotyczącej pojęcia osoby. Wstępnie przedstawiono trzy rozumienia problemu: koncepcję osoby w filozofii naturalistycznej, we współczesnym komunitaryzmie i w jednym ze stanowisk humanistycznych. Analiza tych propozycjo prowadzi do wniosku, że osoba postrzegana jest jako byt empiryczny i psychologiczny lub jako wolny, tworzący siebie podmiot. Stwierdzenie to prowadzi do dalszych badań. W celu uniknięcia pewnego dualizmu w percepcji osoby zakorzenionego we wskazanych wyżej stanowiskach rozwinięte zostaje podejście personalistyczne. Podkreśla się w nim, że osobę należy rozumieć jako niepodzielną całość, lączącą w sobie jaźń - subiektywny aspekt osoby, z naturalno-cielesną stroną, która jest obiektywnym aspektem bytu ludzkiego. W ujęciu personalistycznym osoba jawi się jako wcielona subiektywność utworzona przez akt osobowego istnienia. Wartykule takie rozumienie osoby przedstawione jest jako istotne dla rozwiązywania złożonych problemów bioetycznych.

Słowa kluczowe: osoba, naturalizm, komunitaryzm, humanizm, personalizm

\section{Introduction}

The development of contemporary bioethical thought is dominated by the tendency to abandon any systematic analysis and focus on particular problems. This is largely due to the pragmatic belief that bioethics should deal with resolution of particular cases rather than development of theories of ethics. This view is favoured in American thought in general and in casuistry in particular (Smith 2000, 283). It appears that Albert R. Jonsen captured this well when he said that, "Medical care concerns specific cases. As it deals with the disease and treatment of individuals suffering from specific diseases. Philosophers and

" This article was originally published in Polish as Hołub, Grzegorz. 2005. "Debata na temat koncepcji osoby w bioetyce." Studia Ecologiae et Bioethicae 3: 187-201. The translation of the article into English was financed by the Ministry of Science and Higher Education of the Republic of Poland as part of the activities promoting science - Decision No. 676/P-DUN/2019 of 2 April 2019. Translation made by GROY Translations. 
theologians, involved in medical care, initially tried to refer to standard ethical theories in the analysis of problems arising during therapy. However, they finally admitted that they were discussing cases, not theories. And this has led to the need to develop an approach that puts a specific problem at the centre of analysis, and not a general ethical theory" (Jonsen 1995, 348).

However, further development of bioethics has shown dubious validity of this belief. It transpired that many of the specific problems that arise in the process of therapy cannot be solved if there is no reference to a broader understanding of certain fundamental concepts. One of these key terms is the concept of the person (Doran 1989, 38) ${ }^{1}$. This is due to the fact that all research undertaken by bioethics actually centres around the problems of human life ${ }^{2}$. Hence the understanding of human uniqueness and singularity has become a truly urgent requirement.

Many contemporary bioethicists have taken on the task of rethinking the issues related to human personal life. In the course of this process, some fundamental trends in the formulation of the concept of the person have emerged. Following Sirk$\mathrm{ku}$ K. Hellsten's analysis, three fundamental approaches can be identified: the naturalistic, communitarian, and humanistic concept (Hellsten 2000, 516-517). As it will be more apparent in subsequent sections of this article, these approaches will only be a starting point in the search for more complete solutions.

\section{The Naturalistic Concept of the Person}

The naturalistic approach is based on the basic dichotomy, in which there is a distinction between a human being and

1 This view is supported by the opinion presented by Mary B. Mahowald in The Encyclopedia of Bioethics, who - apart from the material understanding of the concept of the person - said that "(...) the concept of person is of great significance to a variety of issues in contemporary bioethics" (Mahowald 1995, 1940).

2 This view functions within the framework of bioethics understood as a more limited reflection on the issues of life, somewhat abstracted from the problems inherent to environmental ethics. a person ${ }^{3}$. The concept of human being, i.e. human - in the view of the representatives of this school of thought - has only a descriptive relation to particular members of the human race. The concept of the person, on the other hand, has a special value because he or she is a living being who is characterised by being aware and able to make choices. This understanding of human is derived from the thought of English empiricism, and particularly from the definition given by John Locke. He stated that the term person stands for "a thinking intelligent Being, that has reason and reflection, and can consider itself as itself. (...) and by this every one is to himself that which he calls self" (Locke 1955, 471).

In modern naturalistic currents similar definitions can be found as well. Sometimes they are simply repetitions of Locke's definition, but sometimes they indicate additional qualities that clarify the understanding of person as a concept. The contemporary empiricist Derek A. Parfit stated that "to be a person, a being must be self-conscious, aware of its identity and its continued existence over time" (Parfit 1984, 202). Another thinker, John Harris, in a similar fashion asserted that: "A person will thus be any individual capable of valuing its own life. Such a being will - as further noted by Harris - at the very least, be able to conceive of itself as an independent centre of consciousness, existing over time with a future that is capable of envisaging and wishing to experience" (Harris 1983, 225).

Peter Singer, following the same line of thought, pointed out that many animal species, especially mammals, should then also be considered as persons. He believes that animals can be shown to be conscious of their own existence over time and capable of reasoning (Singer 1994, 182). Therefore, "[the] membership of the species

\footnotetext{
${ }^{3}$ Eike-Henner Kluge, a Canadian philosopher, justified this distinction as follows: identification of humanity and personhood is ethically suspect. $\mathrm{Hu}$ manity is a biological concept defined in terms of genetic makeup. Personhood is ethical (...) (Magnet and Kluge 1995, 166).
} 
Homo sapiens- in the view of this thinker does not entitle a being to better treatment than a being at a similar mental level who is a member of a different species" (Singer 1993, 212).

Singer also pointed out an additional criterion of personhood which is the ability to experience pain and suffering. This criterion slightly extends the understanding of person, pointing to an additional aspect apart from the one concerning consciousness and volition. A being who has such characteristics - in the view of this philosopher - should also be considered a person, because this concept, i.e. personhood, cannot be limited only by descriptive factors (self-awareness, freedom). Singer attempted to prove that the fact of experiencing suffering reveals additionally that the term 'person' carries with it a certain moral standing (Singer 1994, 182).

Another naturalistic thinker, Michael Tooley, pointed out that the term person should be presented as a descriptive and not evaluative term (Tooley 1983, 35). In other words, the point is to show a person in the light of such properties that ignore his or her axiological and moral character. Thus, in order to consider a being as a person, he/she must have the following qualifications: the ability to predict his/her own future, the ability to understand oneself (the concept of the existing subject of experience and other mental states), being oneself (being an existing subject of experience), the ability to self-consciousness, having self-awareness (at ones disposal) (Tooley 1973, 59-60).

One of the pioneers of contemporary bioethics, Joseph Fletcher, presented as many as 15 different attributes that must be possessed by a being in order to be a person. It indicates such qualities as: minimum intelligence, self-awareness, self-control, sense (perception) of time, sense of the future, sense of the past, ability to enter into relationships with others, care for others, ability to communicate, control over one's own existence (aspect of freedom), ability to have an interest (curiosity), ability to make changes and changeability, having a balance between rationality and feelings, having identity, uniqueness, cortex functioning (Fletcher 1979, 12-16).

The presented elements of the description of person can be arranged by pointing out a few important aspects. The first - and it would appear the most important - aspect are the factors related to awareness and thinking processes. The second group includes elements related to free will, choice and autonomy. The third one stresses the importance of issues related to the functioning of the nervous system (experiencing pain).

The naturalistic concept of the person leads to certain consequences. Given its assumptions, not only those who belong to the human race should be regarded as persons, as Singer particularly emphasises. Beings who can be shown to have some sort of rational ability and self-awareness, and who are capable of feeling pain, should also be treated as persons in line with this approach. By reversing this view, it must be stated that human beings, who do not currently have these abilities, may not qualify as persons ${ }^{4}$. Here, for example, Singer pointed to people in a coma or in a vegetative state, individuals with severe disabilities, with partial loss of cerebral functions, embryos or even newborns (Singer 1993, 175-217).

The distinction of person and human is a central argument in naturalism. As Hellsten writes, if we treat humanity rather than personhood as such a central criterion then we are in danger of succumbing to speciesism on the basis of a tautology that "the life of human beings has a special value merely because it is human life" (Hellsten 2000, 518). As Hellsten continues, this tautology is problematic for the naturalists

\footnotetext{
${ }^{4}$ In this context, of particular significance are the words of Singer, who said: "When I think of myself as the person I now am, I realise that I did not come into existence until some time after my birth, but only some time after that. At birth I had no sense of the future and no experiences which I can now remember as 'mine'. It is the beginning of the life of the person, rather than of the physical organism, that is crucial so far as the right to life is concerned" (Kuhse and Singer 1985, 133).
} 
to justify because they firmly reject appealing to any 'higher truths' (such as God's will or the inner purposes of nature), and want to present their arguments exclusively on a rational, empirical and secular basis (Hellsten 2000, 518).

\section{Communitarianism on Person}

The view of a person in a communitarian perspective is dominated by opinions contrary to those of naturalism. This is a break with atomistic individualism, which is characteristic of empirical definitions. The implementation of this idea is done by shifting the emphasis from person in relation to itself, to person in its relation to a community.

One of the leading proponents of this school of thought, Mark Kuczewski, stated that: "The communitarian view of the person sees the self as constituted by social roles, communal practices, and shared deliberative exchanges" (Kuczewski 2000, 182). This definition is closely related to the assumption that a person is always rooted in some community. Considering oneself "is inseparable from understanding oneself as a person (...) who is a member of that family, community or nation, who is also the bearer of that history, who is the son or daughter of that revolution, who is finally a citizen of that republic" (Sandel 1982, 179).

The communitarian concept of a person does not therefore regard them as an individual "I". According to Hellsten, "Value and the will of an individual human being continues to be recognized by others, as the self-conscious ' $\mathrm{I}$ ' no longer exists" (Hellsten 2000, 526). Individual features such as the body (and its functions) or the continuity of mental processes, which naturalistic concept considered to be constitutive elements, do not have a conclusive status in the opinion of communitarian thinkers. As Kuczewski states, "a person goes through all these stages, developing personal preferences and acquiring values. (...) The supporting role of the community in this process of self-discovery is part (component) of this process almost as essential as the only (unique) constellation of attributes and feelings of an individual" (Kuczewski 1994, 44).

This sociological (community function-dependent) understanding of personhood means that a person is identified with the identity of an existing individual rather than with some internal attribute, a property that one possesses permanently or only during certain periods of life. Continuity of personal identity is embedded in broadly understood social relations which, in the end, are the guarantee and security of personal status of individual people, members of the community. The consequence of this approach is that it is not awareness-, volitional- and neurological factors that are the criterion for personal life, but the continuity of certain communities. Subsequently, this means that, for example, the fact of losing one's self-awareness or even death does not deprive an individual of their personal status if the community to which they previously belonged still exists (Hellsten 2000, 526).

However, this communitarian view of the person does not resolve all the issues that have emerged in the naturalistic current. If someone has never become a conscious member of a particular community because of, for example, developmental anomaly, that person is almost automatically deprived of their personal status of existence. This is particularly true for individuals who have never had their nervous system properly formed. Another issue of this concept is the quality of relations within certain communities. It is not clear whether individuals who have poor relations with the community or who exist outside these formal environments should be considered as person (Hellsten 2000, 526). It concerns people living in some kind of isolation, including the homeless, the poor and people with alternative lifestyles.

The communitarian understanding of a person - as Hellsten criticises - is not really much different from a naturalistic approach. In empirical thinking, the quality of the functioning of the nervous system, which guaranteed the ability of consciousness and free will, was considered an 
essential criterion for personal life. Communitarianism still uses the same kind of measure, despite the contrary statements by the thinkers of this current. According to Hellsten, "the communitarians see an individual's personhood valuable as long as his or her community is there to identify them as a valuable moral agent; That is, as long as he or she is remembered by their community" (Hellsten 2000, 527). Therefore, the emphasis is shifted from individual consciousness, which is characteristic of naturalistic thought, to collective consciousness. The loss of collective memory (consciousness) that may occur in a given community is then tantamount to the loss of personal status of community members.

H. T. Engelhardt is a thinker who demonstrates the connection between naturalism and communitarianism in a specific way. He is the bioethicist who, by accepting the characteristics of the person presented by naturalism, adds an additional social understanding of the term. In his concept of laic bioethics, he points to a two-way understanding of a person. On the one hand, a person is a being who has a properly formed nervous system and thus has self-awareness and the ability to make choices (current persons, moral agents). On the other hand - and this is a new understanding of the concept - Engelhardt refers to a person as someone who obtains this status by virtue of the decisions of a community of current people. This bioethicist relates this understanding of personality to human beings who do not yet have a properly formed intellectual and volitional power (embryos, newborns and young children), or to those who have already lost that power, as a result of accidents or the ageing process.

Under naturalistic criteria, these beings do not have the status of being a person, but because of their importance to persons in the strict sense, they acquire this status (Engelhardt 1988, 175). This means that the community of current persons in a way gives personal meaning to those who, by virtue of biological or psychological mechanisms, are not entitled to this status. This may be for example due to the importance of this "pre-personal" life for current people $^{5}$ or for relations between them. Therefore, the concept demonstrates how a naturalistic approach to a person can be coherent with sociological and communitarian understanding.

At this level of analysis, some important conclusions are being imposed. Despite Jonsen's declaration of abandoning general theories in favour of particular issues, we note that bioethics is not capable of completely abandoning general yet relevant concepts. An example is an issue discussed in this paper of a person who constantly intrigues a significant group of outstanding bioethics. The second conclusion concerns the methodology for the approach to the concept of the person. The declared desire of empirical thinkers to escape from 'higher truths' (such as God's will or nature's inner purpose) does not end in eliminating them, but in changing the form in which they are present. It may be observed that if a person is not analysed in a transcendental aspect, or in the light of the most general ontological arguments, then the person is considered from the point of view of empirical or sociological sciences. This means that a new type of 'higher truths' is being replaced by what was previously considered to be 'higher truths', only this time these truths reflect more contemporary thinking tendencies.

The third conclusion concerns the concept of the person described in detail in this paper. Viewing the naturalist and communitarian concept in a broader perspective as a single project, it must be stated that this is a kind of methodological error. It is based on the fact that naturalists and communitarians "confuse the concept of personality, as something that is variable and non-essential with the concept of the person, which is

\footnotetext{
${ }^{5}$ Engelhard states in his main work that: "if a human embryo is of a higher moral status than an animal at a similar level of development, (...) it is because of the importance of this life for the woman who conceived it, or for other people interested in this life, or for the future person who may be formed" (Engelhardt 1996, 255).
} 
invariable and essential" (Doran 1989, 41). In other words, there is an identification of personality in the psychological sense (personality) with personality in the philosophical and ontic sense (personhood).

Due to the impossibility of abandoning the general issue in bioethical analyses, which is connected with the necessity of using universal truths ("higher truths"), and due to the tendency to psychologise fundamental philosophical concepts, it is necessary to return unequivocally to strictly understood philosophical analyses of the concept of a person discussed in this paper. Such an attempt was made by the German bioethicist L. Honnefelder.

\section{Towards humanistic concepts}

Honnefelder based his analysis on I. Kant. He questioned the thesis that the assessment of who has the status of a person and who is deprived of it depends on the selected characteristics. In his opinion, it is difficult to explain why particular aspects of human existence have an intrinsic, moral value and are applied as normative criteria in determining whether or not someone is a person and others are ignored. That is why Honnefelder proposes that the whole analysis process should not be applied to the individual as a member of the species, rather to humans as a moral subject (Honnefelder 1996, 144).

This is associated with an unequivocal rejection of the division between human being and person, which is favoured by naturalists. Being recognised as a human being is equivalent to being a criterion for a moral subject. Hence, Honnefelder strongly supports the thesis that "being a person and belonging to the human species are considered inseparable" (Honnefelder 1996, 144). This type of thought follows Kant's line of reasoning. The philosopher, speaking of the ethical implications of this perception of humans, states in a second imperative: "Act in such a way that you treat humanity, whether in your own person or in the person of any other, never merely as a means to an end, but always at the same time as an end" (Kant
1984, 62). Thus, this categorical imperative of reason confirms that humanity is inseparably connected to the person, constituting a moral entity which is an end in itself.

Honnefelder defines a person as a moral subject, who is defined not only beyond a naturalistic (biological) perspective, but also beyond metaphysical considerations. The idea is to refer to the concept of a person as a practical concept, which is not culled from metaphysics but has its own and original meaning (Honnefelder 1996, 146). Then the person is seen as an "entity who is able to determine their own goals and can take responsibility for their own realization"; in other words, it refers to the person as "a human being, to whom an unrestricted list of mental and material predictions that implicate each other may be applied" (Honnefelder 1996, 156).

Honnefelder's proposal is radically different from naturalistic approaches. This is primarily the result of viewing a person from the point of view of European continental philosophy, or more specifically from the point of view of German philosophy. In this perspective, man is seen more in the light of the peak possibilities and achievements inherent in his existence. This approach is contrary to the one that functions in English-language thought, where the human being is defined in terms of his or her minimum potential and activity.

However, it seems that this concept tends to spiritualise the human person to some extent by departing from empirical thinking. This suspicion results from the fact that man is perceived as an autonomous centre which, by the power of its mental capacity, defines itself, its goals. However, the question of human corporeality remains questionable. It seems that the moral agent-person creates his or her own goals, including those related to the functioning of the human body. In bioethics, the function of human corporeality (the positive function of human corporeality) is an extremely important issue ${ }^{6}$. Hence, this concept, which may

${ }^{6}$ Doucet draws attention to this in the context of all bioethics, saying: "One critical and prophetic task for ethics is to reintegrate the body into our vision 
seem slightly controversial, provides stimulation for further, more adequate descriptions of the human person.

\section{Personalistic bioethics about a person}

Within the framework of the personalistic approach, there are several positions that use the concept of a person. Strictly speaking, the term cannot be regarded as a single concept appropriate for the broadly defined field of experimental sciences ${ }^{7}$. Therefore, it seems that the common view shared by personalist philosophers is that "a predicate such as a 'person' (...) is not an empirical or scientific concept, and therefore is not of a descriptive nature but it rather constitutes a predicate of a moral, ontological and metaphysical nature (Bellino 1995,93$)^{8}$. A review of some of the anthropological proposals that are specific to such a perception of human life should point out the reasons behind it.

It seems that the most classical understanding of a person in bioethics, which follows this line of thinking, is the one used by E. Sgreccia. In his opinion, "for bioethics, a human person is a fundamental value, a criterion of discernment and an objective of moral action" (Sgreccia 1998, 96). In his main work, this thinker states that "the focus of the notion of a person is to define the person within the reality that forms him or her, beyond the very consciousness that is characteristic of all per-

of the human being and of the subject of research" (Doucet 2001, 127).

${ }^{7}$ Referring to C. Vigna's view, Bellino points out that no descriptive statements - characteristic of experimental sciences - such as ' $x$ is conscious', ' $x$ suffers', ' $x$ is happy', logically suggest that ' $x$ is a person' (Bellino 1997, 106).

${ }^{8}$ Palazzani confirms this thesis by stating that "the recognition of the personal status of a human being means the ability to say something more about a human than is indicated by the set of empirical characteristics of a human being itself. The actual identification of human existence with a person expresses, on a philosophical and anthropological level, a human's own character and their constitutive features. Thanks to that, the foundation of their values and rights as well as the objective foundation of their duty to respect and protect can be identified in the last resort (Palazzani 1996, 220). sons and beyond the expressive possibilities that each individual person acquires in the process of maturation" (Sgreccia 1991, 78). This statement quite clearly suggests that by defining the concept of a person, Sgreccia wants to use tools appropriate for metaphysical analyses.

When presenting his understanding of a person, Sgreccia evokes the idea of Boethius as a necessary starting point for a proper understanding of this essential notion. Boethius (5th-6th century) formulated the definition of a person in the context of Christological disputes. In his work De duabus naturis et una persona Christi, he provided the following definition: persona est rationalis nature individua substantia. In this definition, three basic elements characterising a person can be distinguished: a person is a substance, a unique (individual) being, and a person possesses a rational nature.

The substantiality of a person indicates their real existence. Sgreccia defines this aspect of personal life as follows: "A person is (...) a real being (prime matter in Aristotle's terminology), a particular existence which concretises a general and abstract kind of being (secondary matter) in a single individual. Existence indicates the existence of a person in and by themselves, by virtue of their own act of existence" (Sgreccia 1995, 191).

The individual character of a person's existence defines him or her as a unique being, which stands out from other people through his or her corporeality. Here, Sgreccia points to corporeality as the moment of materialisation of form (la materializzazione della forma); on the other hand, corporeality is seen as giving existence to the essence (lexenzializzazione dellessen$z a$ ) and as the moment when corporeality is the incarnation of the spirit (lincarnazione dello spirit) (Sgreccia 1995, 191).

The rational nature of a person allows them to approach the world rationally, which is expressed in the possibility of making generalisations, abstractions, creating projects and grasping the sense of things. As Sgreccia notes, the human person not 
only possesses active rationality, but above all, it is its nature to be personal. This means that when a person does not exhibit active rational acts, for example due to their health condition, this does not mean a loss of rationality. Acts are merely a manifestation of rational nature but they do not exhaust it (Sgreccia 1995, 191).

The classical concept of a person presented by E. Sgreccia departs radically from the understanding of this category presented by the naturalists, and significantly extends the understanding of this concept in relation to Honnefelder's proposal. The basic differentiating element of this project is the tendency to describe the human person in an integral way as an indivisible whole. It is expressed in describing a human being using the ontic term of a substance that possesses a rational nature.

This approach is close to other personalistic thinkers. One of them is W. E. May, who clearly opposes these two tendencies (naturalistic and idealistic), emphasising the integral belonging of the human body to the essence of being a person. He states that "life is not one of many processes; it is not a process that can be compared to breathing, feeling, choosing, speaking and so on. A person's life cannot really be distinguished from the true reality of the person: it permeates all its elements (parts) and activities (actions). The human person is more than the human body, but the human person's body is an integral part of being a person. When this body dies, the person dies" (May 1998, 48).

This statement leads to a thesis that very clearly strikes both at naturalistic and idealistic thinking about the person. May points out that the basic human activity, the activity of a person, is not possessing, but fulfilling one's existence (May $1998,48)$. In more general terms, it can be said that a resist reference to corporeality, whether by defining it as the exclusive domain of empirical processes or by making it the exclusive subject of creative activity, is excluded. In this perspective, corporeality is not something that a person has and can dispose of as a thing (also by treating the body as a purely biological reality). The human body has an inner personal value - it is a constitutive element of a person, an external (but not separated, heteronomous) manifestation of personal life.

The attribution of inner, personal value to human corporeality is closely linked to the indication of its inner purpose. For if it is not a sub-personal reality, governed solely by biological processes, then corporeality, as a constitutive element of a person, has its own internal goals, which at the same time constitute the goals of personal life, goals of the person. It is only in this context that one can understand the distinction between "possession" and "fulfilment" presented above. Corporeality is not an object to be possessed; it participates in human fulfilment.

Indicating the unity of the physical and spiritual aspect of a person constitutes a clear opposition to the dualism functioning in modern bioethics: a person is consciousness and freedom, or a person is corporeality with a whole range of empirical processes constituting it ${ }^{9}$. Demonstrating that this alternative is disastrous for bioethics is the aim of the philosophical considerations of German personalist R. Speamann. He is trying to show that there is a close convergence between the concept of the person and the concept of human. He says: "There can only be one criterion for being a person: biological belonging to the human race. Therefore, the beginning and end of a person's existence cannot be separated from the beginning and end of human life. If 'someone' exists, he or she has existed since this individual human organism came to existence and will continue to exist as long as this organism is alive. A person's being is the life of a human. (...) A person is a human being, not a characteristic of a human being" (Spaemann 2001, 305). This last thesis refers to the above-mentioned May's thought. A person is not a feature

\footnotetext{
${ }^{9}$ This issue is addressed in more detail by B. Chyrowicz, who described and analysed this problem as the separation of nature from the person (Chyrowicz 2000, 227).
} 
or a thing that can be defined by verbs such as acquiring, losing, disposing of, improving or deteriorating (depleting). All of these qualifiers concern personal qualities, in a psychological rather than a philosophical sense. The human being invariably enjoys the status of a person as long as he or she is human. But being human, being "somebody," is a radically different way of life than in the case of things, as being "something".

The idea of the Polish personalist and phenomenologist K. Wojtyła can be used to express this thesis. He explicitly indicates that "man is objectively "somebody" - and this is what separates him from the rest of the beings of the visible world, which objectively are always "something". This simple, elementary distinction hides a deep gap that divides the world of people and things (Wojtyła 1986, 24) ${ }^{10}$. Undoubtedly, this theory refers to a peculiar intuition of man, which makes him into a being that cannot be reduced to other beings. For if everything that exists can be judged in terms of acquisition, loss, disposition, improvement or deterioration, then in relation to a person it seems clearly inadequate; referring the above to a person is acceptable at most in a figurative sense, or when very specific aspects of human life are taken into account (e.g. personality can be improved in the psychological sense (i.e. personality traits)). The description of philosophically ${ }^{11}$ understood personality in qualitative and quantitative terms clearly goes against the intuitive sense

\footnotetext{
${ }^{10}$ Another personalist-phenomenologist, referring to this important distinction and evoking the subjective experience of himself, asks: "Can we say that although we experience ourselves as immersed in the world of the things around us, perhaps even "as one" with them, we as individuals are in fact not one with anything; we are ourselves, rather than anybody else, in an incommunicable way; and that this subjective self-experience (of ourselves as immersed in the world of things), in states of distraction, is contrary to who we really are as people?" (Crosby 1993, 402).

${ }^{11}$ In English, this distinction is indicated by two different terms: personhood - a person in the philosophical sense, personality - a person as a psychologically understood personality.
}

of greatness and uniqueness of a human person. Referring to analogous thinking, it can be argued that this intuition is well expressed by the principle of the excluded middle. There is no intermediate state between being a person and a non-personal being. It is impossible to just partly be a person, or be a person more or less intensely. The idea of describing a person by pointing out the gradation of becoming should also be excluded. If one can even talk about the gradualness of becoming, it is only in the epistemic sense, not in the ontic sense, indicating the stage of a person's becoming. In brief, it can be said that if something came into existence, it has existed from the beginning either as a person or as a non-personal being.

\section{Conclusions: a person in bioethical analysis}

Several of the presented proposals for describing human beings confirm that this problem is still important and it would be difficult to talk about ending the discussion on this issue. As it was pointed out in the introduction, its importance is primarily due to the fact that most of the bioethical problems concern humans. Therefore, any attempt to solve particular issues refers openly or implicitly to some sort of understanding of the human-person.

The concepts outlined are based on various personality criteria (person-hood). On the one hand, the criteria related to the functioning of the neuro-cerebral system are indicated, which are the basis for the somatic occurrence of individual or, consequently, collective consciousness. This group also includes factors that determine the autonomy of an individual. They are generally of an empirical nature: they indicate at most the psychosomatic aspects of a person ${ }^{12}$. On the other hand, the criterion of moral subjectivity of a person is indicated. This approach, in turn, goes the other way and has a tendency to spiritualise the human-person (man as an autocreative spirit).

12 Teichman describes this way of looking at a person as a brains-plus-nervous-system concept (Teichman 1985, 176). 
The position that seems to be a more appropriate solution to this problem in bioethics is personalism. It recognises the individual as an incarnate entity. Thus, the touchstone that decides about the personal life is not empirical and psychological or spiritualistic factors; it is rather an act of existence specific to a given person. It forms all the rich phenomena of spiritual and subjective life and permeates those inherent in corporeality. The personal act of existence makes corporeality participate in personal life, becoming an inseparable aspect of the person. Thus, corporeality in this perspective - is not merely a biological organism or material, an object for the creative function of the mind.

The last of the presented positions, which can be described as ontological personalism, is very helpful in solving even complicated moral cases in the medical environment. In order to avoid reducing human life to some selected, individual characteristics, on the one hand, or making its value dependent on, sometimes extremely complicated, processes or institutional procedures (Viafora 1993, 34), on the other hand, it is necessary to have a clear intuition of a person, which has the right theoretic (metaphysical and anthropological) foundation. The use of the integral concept of a person, proposed by ontological personalism helps to organise the theoretical assumptions with which one enters into the maze of practical actions and procedures, as well as to shape an approach in which the person is at the centre of the therapeutic action.

\section{Bibliography}

Bellino, Francesco. 1995. "Bioetica e principi del personalismo." In Bioetica fondamentale e generale, ed. Giovanni Russo. Torino: Societa Editrice Internazionale.

Bellino, Francesco. 1997. "Problemi della bioetica e rispetto della persona." In Antropologia e bioetica. Ricerca interdisciplinare sull'enigma uomo, ed. Battista Mondin. Milano: Massimo.

Chyrowicz, Barbara. 2000. Bioetyka i ryzyko. Lublin: KUL.
Crosby, John. F. 1993. "Personhood of the Human Embryo." The Journal of Medicine and Philosophy 4: 399-417.

Doran, Kevin. 1989. "Person - A Key Concept for Ethics." Linacre Quarterly 4: 38-49.

Doucet, Hubert. 2001. "Concept of Person in Bioethics." In Personhood and Health Care, edited by David C. Thomasma, David N. Weisstub, and Christian Hervé, 121-128. Dordrecht: Kluwer Academic Publishers.

Engelhardt, Hugo T. 1988. "Medicine and the Concept of Person." In What Is a Person?, edited by Michael F. Goodman, 169-184. New Jersey: Human Press.

Engelhardt, Hugo T. 1996. Foundations of Bioethics. New York: Oxford University Press.

Fletcher, Joseph. 1979. Humanhood: Essays in Biomedical Ethics. New York: Prometheus Books.

Harris, John. 1983. "In Vitro Fertilisation. The Ethical Issues." The Philosophical Quarterly 132: 217-238.

Hellsten, Sirkku K. 2000. “Towards an Alternative Approach to Personhood in the End of Life Questions." Theoretical Medicine 21: 516-517.

Honnefelder, Lutger. 1996. "Concept of a Person in Moral Philosophy." In Sanctity of Life and Human Dignity, edited by Kurt Bayertz, 139160. Dordrecht: Kluwer Academic Publishers. Jonsen, Albert R. 1995. "Casuistry." In Encyclopedia of Bioethics, edited by Warren T. Reich, vol. I, 348. New York: Simon Schuster Macmillan.

Kant, Immauel. 1984. Uzasadnienie metafizyki moralności. Warszawa: Wydawnictwo Naukowe PWN.

Kuczewski, Mark. 1994. "Whose Will Is It, anyway? A Discussion of Advance Directives, Personal Identity, and Consensus in Medical Ethics." Bioethics 1: 27-48.

Kuczewski, Mark. 2000. "Can Communitarianism End to Shrill and Interminable Public Debates? Abortion as a Case-in-Point." In Bioethics. Ancient Themes in Contemporary Issues, edited by Mark Kuczewski, and Ronald Polansky, 179-191. Cambridge (MA): The MIT Press.

Kuhse, Helga, and Peter Singer. 1985. Should the Baby Live? The Problem of Handicapped Infants. Oxford: Oxford University Press. 
Locke, John. 1955. Rozważania dotyczace rozumu ludzkiego. Warszawa: Wydawnictwo Naukowe PWN.

Magnet, Joseph E., and Eike-Henner Kluge. 1995. Withholding Treatment from Defective Newborn Children. Cowamsville (Quebec): Brown Legal Publications.

Mahowald, Mary B. 1995. "Person." In Encyclopedia of Bioethics, edited by Warren T. Reich, vol. I, 1940. New York: Simon Schuster Macmillan.

May, William E. 1998. "Bioethics and Human Life." In Natural Law and Contemporary Public Policy, edited by David F. Forte, 41-54. Washington: Georgetown University Press.

Palazzani, Laura. 1996. II concetto di persona tra bioetica e diritto. Torino: G. Giappichelli Editore.

Parfit, Derek. 1984. Reasons and Persons. Oxford: Clarendon Press.

Sandel, Michael J. 1982. Liberalism and the Limits of Justice. Cambridge: Cambridge University Press.

Sgreccia, Elio. 1991. Manuale di bioetica, vol. 1, Milano: Vita e Pensiero.

Sgreccia, Elio. 1995. "La persona umana." In Bioetica, ed. Carlo Romano, e Goffredo Grassani. Torino: UTET.
Sgreccia, Elio. 1998. "La bioetica personalista." In Le radici della bioetica, ed. Elio Sgreccia, Vincenza Mele, Gonzalo Miranda, vol. 1, 85108. Milano: Vita e Pensiero.

Singer, Peter. 1993. Practical Ethics. Cambridge: Cambridge University Press.

Singer, Peter. 1994. Rethinking Life and Death. The Collapse of Our Traditional Ethics. Melbourne: Text Publishing Company.

Smith, Iltis Ana. 2000. "Bioethics as Methodological Case Resolution: Specification, Specified Principlism and Casuistry." The Journal of Medicine and Philosophy 3: 271-284.

Spaemann, Robert. 2001. Osoby. O różnicy między czymś a kimś. Warszawa: Oficyna Naukowa.

Teichman, Jenny. 1985. "The Definition of Person." Philosophy 60: 175-185.

Tooley, Michael. 1973. "A Defence of Abortion and Infanticide." In The Problem of Abortion, edited by Joel Feinberg, 51-91. Belmont: Wadsworth Publishing Company.

Tooley, Michael. 1983. Abortion and Infanticide. Oxford: Clarendon Press.

Viafora, Corrado. 1993. "I principi della bioetica." Bioetica e cultura 3: 9-38.

Wojtyła, Karol. 1986. Miłość $i$ odpowiedzialność. Lublin: KUL. 